\title{
Pengaruh insentif terhadap peningkatan kinerja pustakawan di perpustakaan UNIMED
}

\author{
Tessa Simahate
}

\begin{abstract}
This article discusses the effect of incentives on improving librarian performance in the UNIMED library. Based on the results of research on the effect of giving incentives to improve the performance of library librarians in Medan State University as follows: 1). There is a significant influence between giving incentives to improving the performance of the Library of Medan State Library with a calculated value of 0.679 and rtable of 0.334 , meaning that $r$ count $>r$ table is 0.679> 0.33. And the discrimination coefficient (D) is 49.10\%. 2). The results of the hypothesis obtained by tcount of 5.312 and table of 1.70. From these results, the tcount $>t$ table is 5.312> 1.70, so that the conclusions obtained in this study are that there is a significant influence between giving incentives to improving the performance of the Library of Medan State Library (Ha accepted and Ho rejected).
\end{abstract}

Keywords: Performance, Librarians, Incentives, UNIMED

\section{Pendahuluan}

Perpustakaan merupakan institusi pemberi layanan jasa, sebagai lembaga yang memberikan pelayanan di bidang jasa pustakawan yang melayani pemustaka harus mampu memberikan pelayan prima, maka pustakawan harus senantiasa meningkatkan kinerja dan memberikan layanan terbaik kepada pemustaka, hal ini di karenakan tingkat kinerja pustakawan berbanding lurus dengan pemenuhan kebutuhan pemustaka. Evaluasi pelayanan biasanya dilakukan di setiap lembaga secara berkala di dalam internal organisasi. Perpustakaan yang akan mengevaluasi tingkat kinerja dalam internal organisasi biasanya akan menentukan indikator keberhasilannya sesuai dengan tujuan suatu lembaga, namun secara internasional sudah ditetapkan standar pengukur kinerja perpustakaan yaitu yang diterbitkan dalam ISO 11620 . 
Dengan indikator ini diharapkan perpustakaan dapat memberikan yang terbaik dan menciptakan iklim kerja yang kompetitif.

Pemberdayaan pustakawan sebagai pilar utama dalam mengedepankan pelayanan prima merupakan suatu keharusan, motivasi kerja menjadi hal yang penting karena dengan ini diharapkan setiap individu karyawan mau bekerja keras dan antusias untuk mencapai produktivitas kerja yang tinggi. Menurut Anoraga (1994:92 dalam Koesindratmono dan Septarani, 2011) motivasi kerja merupakan sesuatu yang menimbulkan semangat atau dorongan untuk bekerja, sedangkan menurut Hasibuan (1994:92 dalam Koesindratmono dan Septarani, 2011) motivasi mempersoalkan bagaimana mendorong gairah kerja agar mereka mau bekerja keras dengan memberikan kepada manusia, khususnya kepada para bawahan atau pengikut agar mereka mau bekerja keras dengan memberikan semua kemampuan dan keteram pilannya untuk mewujudkan tujuan perusahaan. Masalah motivasi merupakan masalah utama yang terjadi pada setiap organisasi, karena motivasi dalam suatu organisasi mempunyai pengaruh terhadap efektifitas organisasi

Insentif merupakan merupakan salah satu upaya untuk meningkatkan motivasi. Banyak lembaga atau institusi memberikan kompensasi berupa insentif sebagi imbalan dalam meningkatkan kinerja yang memenuhi target. Pemberian insentif ini bertujuan untuk merangsang motivasi pustakawan dalam meningkatkan kinerja.

Salah satu faktor penyebab turunnya motivasi kerja pustakawan adalah rendahnya insentif ekonomi, sedangkan pustakawan sangat berperan penting dalam meningkatkan atau mencapai tujuan peepustakaan, maka pemberian insentif yang memadai kepada pustakawan perlu mendapatkan perhatian khusus sehingga mereka dapat melaksanakan tugasnya dan dapat mengembangkan kemampuan mereka semaksimal mungkin. 
Insentif sangat diperlukan untuk memacu kinerja para pustakawan agar selalu berada pada tingkat tertinggi (optimal) sesuai kemampuan masing-masing. Peran insentif cukup besar dalam membentuk pustakawan potensial. Insentif merupakan salah satu bentuk pemberian gaji, upah, dan penghargaan yang diberikan kepada pustakawan terkait dengan kontribusi pustakawan dalam pencapaian tujuan institusi. Pemberian insentif yang tinggi dan relevan pada saat pustakawan bekerja akan berpengaruh terhadap kinerja pustakawan. Pemberian insentif dirasa sangat penting bagi pustakawan mengingat terlalu banyak kebutuhan pustakawan dan diharapkan insentif mampu meningkatkan kesejahteraan hidup pustakawan. Selain itu, insentif dapat memberikan motivasi kepada pustakawan agar mampu meningkatkan kinerjanya

Banyak penelitian yang menyimpulkan bahwa tingkat kesejahteraan pustakawan berpengaruh signifikan terhadap kinerja, namun demikian tidak sedikit pula institusi yang menilai bahwa pemberian insentif tidak berpengaruh terhadap kinerja institusinya. Hal ini terjadi di lembaga - lembaga milik pemerintah. Ada kemungkinan hal ini juga terjadi di perpustakaan yang notabene tingkat kompetensi kerja tidak setinggi di perusahaan - perusahaan milik swasta. Tidak dapat kita pungkiri bahwa masih ada keluhan dari masyarakat tentang rendahnya kualitas layanan di perpustakaan. Pemberian insentif yang bertujuan untuk memperbaiki kinerja pustakawan ini diharapkan tepat sasaran, maka sejatinya diperlukan evaluasi internal sebuah organisasi, dalam penerapan kebijakan ini secara berkesinambungan. UPT. Perpustakaan UNIMED memiliki 36 orang pustakawan, serta pemberian insentif kepada pustakawan sudah lama diberlakukan, maka peneliti memilih mengadakan penelitian di UPT. Perpustakaan Unimed. Untuk mengetahui sejauh mana pengaruh pemberian insentif terhadap peningkatan 
kinerja pustakawan, maka peneliti tertarik untuk meneliti lebih lanjut dengan judul "Pengaruh Insentif Terhadap peningkatan Kinerja Pustakawan di Perpustakaan UNIMED".

\section{Identifikasi Masalah}

Berdasarkan gambaran fenomena dan latar belakang masalah di atas, maka identifikasi masalah dalam penelitian ini adalah

1. Bagaimana motivasi kerja para pustakawan di lingkangan perpustakaan UNIMED

2. Bagaimana pendapat para pustakawan tentang insentif yang di dapatkan selama ini.

3. Bagaimana insentif dapat mempengaruhi motivasi kerja bagi para pustakawan di perpustakaan UNIMED.

\section{Tujuan Penelitian}

Tujuan dari penelitian ini adalah untuk mengetahui pengaruh insentif terhadap motivasi parapustakawan di perpustakaan Universitas Negeri Medan.

\section{Manfaat Penelitian}

Adapun manfaat penelitian ini adalah

1. Manfaat penelitian ini kepada institusi yang di teliti adalah sebagai masukan untuk membina para pustakawan di internal perpustkaan.

2. Manfaat penelitian ini kepada peneliti adalah agar menegtahui sejauh mana insentif dapat mempengaruhi motivasi kerja para karyawan.

3. Manfaat penelitian ini untuk peneliti selanjutnya adalh untuk menjadi acuan penelitian serupa di kemudian hari.

\section{Kajian Teori}

\section{Pengertian Insentif}

Bekerja bagi seseorang atau individu merupakan usaha untuk mencari nafkah, selain bekerja adalah sarana aktualisasi dirinya, menginginkan imbalan yang sesuai dengan keahlian dan pekerjaan merupakan hal yang sangat manusiawi. Kompensasi 
selain sebagai alat pemenuhan kebutuhan materiil, dewasa ini juga dikaitkan dengan gengsi atau melambangkan prestise seseorang.

Kompensasi insentif adalah program-program kompensasi yang mengaitkan bayaran dengan produktivitas (Simamora 1997 dalam Kadarisman 2012:182). Sedang menurut Yuniarsih dan Suwatno (2008 dalam Kadarisman 2012:191) mengemukakan sebagai berikut:

"Insentif adalah penghargaan/imbalan yang diberikan untuk memotivasi pekerja/anggota organisasi agar motivasi dan produktivitas kerjanya tinggi, sifatnya tidak tetap atau sewaktuwaktu."

Menurut Mangkunegara, insentif adalah suatu penghargaan dalam bentuk uang yang diberikan oleh pihak pemimpin organisasi kepada pustakawan agar mereka bekerja dengan motivasi yang tinggi dan berprestasi dalam mencapai tujuantujuan organisasi atau dengan kata lain, insentif kerja merupakan pemberian uang diluar gaji yang dilakukan oleh pihak pemimpin organisasi sebagai pengakuan terhadap prestasi kerja dan kontribusi pustakawan kepada organisasi. (Mangkunegara, 2009 : 89)

Pada dasarnya insentif ini adalah penghargaan yang diberikan kepada pustakawan yang melaksanakan pekerjaan sesuai atau melebihi target yang telah ditetapkan.

Hasibuan mengelompokkan insentif berdasarkan jenisnya menjadi 3 jenis, yaitu

1. Materiil Insentif : alat motivasi yang diberikan itu berupa uang dan atau barang yang mempunyai nilai pasar; jadi memberikan kebutuhan ekonomis. Misalnya kendaraan, rumah dan lainlainnya.

2. Nonmateriil Insentif : alat motivasi yang diberikan itu berupa barang/benda yang tidak ternilai; jadi hanya memberikan 
kepuasan/kebanggaan rohani saja. Misalnya medali, piagam, bintang jasa, dan lain-lainnya.

3. Kombinasi Materiil dan Non Materiil : alat motivasi yang diberikan itu berupa materiil (uang dan barang) dan nonmateriil (medali dan piagam); jadi memenuhi kebutuhan ekonomis dan kepuasan/kebanggaan rohani. (Hasibuan, 2007 : 99)

Dessler menyatakan bahwa insentif berupa uang merupakan alat utama untuk memotivasi pegawai. (Dessler, 1984 : 412)

Untuk meningkatkan produktivitas perpustakaan maka pelaksanaan sistem upah insentif di berlakukan, dan mempertahankan pustakawan yang berprestasi untuk tetap berada dalam perpustakaan. Dengan demikian upah insentif sebenarnya merupakan suatu bentuk motivasi yang dinyatakan dalam bentuk uang. (Ranupandojo dan Suad Husnan, 1996 : 161)

\section{Kinerja Pustakawan}

Kinerja adalah capaian prestasi kerja individu maupun kelompok dalam suatu pekerjaan dengan tujuan yang telah ditentukan bersama sebelumnya. Kinerja adalah hasil kerja yang dapat dicapai seseorang atau kelompok orang dalam suatu organisasi sesuai dengan wewenang dan tanggungjawab masingmasing dalam rangka upaya mencapai tujuan organisasi yang bersangkutan secara legal tidak melanggar hukum dan sesuai dengan moral dan etika. (Prawirosentono, 1999 : 2) .

Kinerja atau sering disebut unjuk kerja merupakan hasil kerja yang dihasilkan oleh pegawai atau perilaku nyata yang ditampilkan sesuai dengan perannya dalam organisasi (Harinandja, 2002: 195). Adapun professional bersangkutan dengan profesi yang memiliki arti pekerjaan yaitu pekerjaan yang memerlukan pendidikan dan latihan. Suatu pekerjaan disebut profesi bila memiliki ciri-ciri antara lain: (a) adanya asosiasi atau organisasi keahlian, (b) terdapat pula pendidikan yang jelas, (c) 
adanya kode etik, (d) berorientasi pada jasa, dan (e) adanya tingkat kemandirian (Sunarti, 1996: 31)

Dari definisi-definisi diatas jika diterapkan pada kepustakawanan, dapatlah dikatakan bahwa "tugas-tugas profesional" adalah tugas-tugas pelaksanaan yang memadai yang menyangkut kemampuan mempertimbangkan secara mandiri berdasarkan pemahaman prinsip-prinsip layanan perrpustakaan, pemakai publikasi dan informasi serta cara menghubungkan kedua hal itu secara mangkus. Pemahaman ini menyiratkan pengetahuan yang luas mengenai teknik dan prosedur khusus perpustakaan.

Hampir sama dengan pengertian kinerja yang lain, menurut Mangkunegara kinerja adalah hasil kerja secara kualitas dan kuantitas yang dicapai oleh seorang pegawai dalam melaksanakan tugasnya sesuai dengan tanggung jawab yang diberikan kepadanya. (Mangkunegara, $2009: 67$ )

Adapun aspek-aspek yang dapat mengukur kinerja pustakawan menurut Tizan Herman dan Kianta (dalam Fatimah, 2001: 27), sebagai berikut: (1) kinerja pelayanan dapat diandalkan dan akurat sehingga tingkat kesalahan dapat diperkecil (reliabilitas), (2) pustakawan mampu memberikan jawaban kepada setiap permintaan dalam waktu relatif singkat (responsive), (3) setiap pustakawan harus bersikap sopan, hormat dan ramah serta mampu berkomunikasi dengan pemakai, (4) pustakawan harus mampu menciptakan pelayanan yang memiliki kredibilitas yang tinggi, (5) pelayanan harus dapat menjamin keselamatan fisik, keuangan dan bahan-bahan lain yang dianggap rahasia, (6) pustakawan harus mampu memahami menggali dan mengidentifikasi pemakai, dan (7) ruangan dan peralatan harus nyaman dan tertata dengan baik (tangible). 


\section{Kerangka Konseptual}

Kerangka konseptual adalah kerangka hubungan antara variabelvariabel yang akan di uji dan diteliti melalui penelitian yang akan dilakukan. Berdasarkan latar belakang dan tinjauan pustaka di atas, maka peneliti dapat membuat kerangka sebagai berikut:

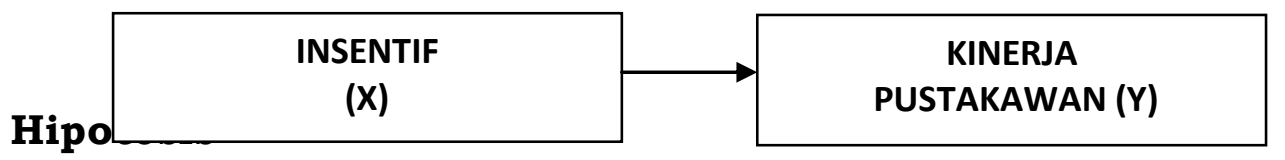

Hipotesis dapat diartikan sebagai suatu jawaban yang bersifat sementara terhadap masalah yang diajukan, dan jawaban itu masih akan diuji secara empiris kebenarannya. Hipotesis dalam penelitian ini adalah Insentif berpengaruh signifikan terhadap peningkatan Kinerja Pustakawan di Perpustakaan UNIMED

\section{Metode Penelitian}

Jenis penelitian ini adalah deskriptif korelasi. Penelitian deskriptif korelasi artinya seluruh data yang diperoleh dari penelitian ini akan digunakan untuk melihat hubungan antar dua variabel yang diteliti. (Nawawi, 1994 : 108). Penelitian ini menggunakan teknik sampling jenuh, yaitu teknik penentuan sampel bila semua anggota populasi digunakan sebagai sampel. Hal ini dilakukan bila jumlah populasi relatif kecil, kurang dari 30 orang. (Sugiyono, 2000 : 62). Dalam penelitian ini sampel yang digunakan sebanyak 35 orang pengelola perpustakaan di UPT. Perpustakaan Universitas Negeri Medan.

\section{Hasil Penelitian Dan Pembahasan}

\section{Deskripsi Data Penelitian}

Data yang diuraikan pada sub bahasan ini adalah hasil jawaban dari 35 pegawai dalam 8 item angket mengenai kinerja pustakawan perpustakaan UNIMED dan 11 item angket mengenai pemberian insentif. 


\section{Angket untuk variabel Y: Kinerja Pustakawan Perpustakaan UNIMED}

Perolehan hasil angket yang terdiri dari 8 butir pernyatan adalah sebagai berikut.

Tabel 4.1. Skor Angket Variabel Y

\begin{tabular}{|c|c|c|c|c|c|c|c|c|c|}
\hline \multirow{2}{*}{$\begin{array}{c}\text { Nomor } \\
\text { Responden }\end{array}$} & \multicolumn{8}{|c|}{ Nomor Butir Angket } & \multirow{2}{*}{ Jumlah } \\
\hline & 1 & 2 & 3 & 4 & 5 & 6 & 7 & 8 & \\
\hline 1 & & & & & & & & & 26 \\
\hline 2 & & & & & & & & & 21 \\
\hline 3 & & & & & & & & & 21 \\
\hline 4 & & & & & & & & & 22 \\
\hline 5 & & & & & & & & & 20 \\
\hline 6 & & & & & & & & & 24 \\
\hline 7 & & & & & & & & & 21 \\
\hline 8 & & & & & & & & & 22 \\
\hline 9 & & & & & & & & & 24 \\
\hline 10 & & & & & & & & & 20 \\
\hline 11 & & & & & & & & & 23 \\
\hline 12 & & & & & & & & & 23 \\
\hline 13 & & & & & & & & & 24 \\
\hline 14 & & & & & & & & & 24 \\
\hline 15 & & & & & & & & & 18 \\
\hline 16 & & & & & & & & & 21 \\
\hline 17 & & & & & & & & & 20 \\
\hline 18 & & & & & & & & & 27 \\
\hline 19 & & & & & & & & & 15 \\
\hline 20 & & & & & & & & & 23 \\
\hline 21 & & & & & & & & & 21 \\
\hline
\end{tabular}




\begin{tabular}{|c|l|l|l|l|l|l|l|c|c|}
\hline $\mathbf{2 2}$ & & & & & & & & & 18 \\
\hline $\mathbf{2 3}$ & & & & & & & & & 21 \\
\hline $\mathbf{2 5}$ & & & & & & & & & 25 \\
\hline $\mathbf{2 6}$ & & & & & & & & & 24 \\
\hline $\mathbf{2 7}$ & & & & & & & & & 26 \\
\hline $\mathbf{2 8}$ & & & & & & & & & 17 \\
\hline $\mathbf{2 9}$ & & & & & & & & & 19 \\
\hline $\mathbf{3 0}$ & & & & & & & & & 19 \\
\hline $\mathbf{3 1}$ & & & & & & & & & 20 \\
\hline $\mathbf{3 2}$ & & & & & & & & & 23 \\
\hline $\mathbf{3 3}$ & & & & & & & & & 24 \\
\hline $\mathbf{3 4}$ & & & & & & & & 21 \\
\hline $\mathbf{3 5}$ & & & & & & & 17 \\
\hline & & & & & & & & \\
\hline
\end{tabular}

Berdasarkan Tabel 4.1 di atas diperoleh data kinerja pada pustakawan di Perpustakaan Universitas Negeri Medan sebanyak 35 orang dengan 8 angket diperoleh nilai terendah 15 dan nilai tertinggi 27.

\section{Angket untuk variabel $X$ : Pemberian Insentif}

Perolehan hasil angket terdiri dari 11 butir pernyataan adalah sebagai berikut.

Tabel 4.2. Skor Angket Variabel X

\begin{tabular}{|c|c|c|c|c|c|c|c|c|c|c|c|c|}
\hline \multirow{2}{*}{$\begin{array}{c}\text { Nomor } \\
\text { Responden }\end{array}$} & & \multicolumn{10}{|c|}{ Nomor Butir Angket } & \multirow{2}{*}{ Jumlah } \\
\hline & 1 & 2 & 3 & 4 & 5 & 6 & 7 & 8 & 9 & 10 & 11 & \\
\hline 1 & & & & & & & & & & & & 36 \\
\hline 2 & & & & & & & & & & & & 32 \\
\hline 3 & & & & & & & & & & & & 36 \\
\hline
\end{tabular}




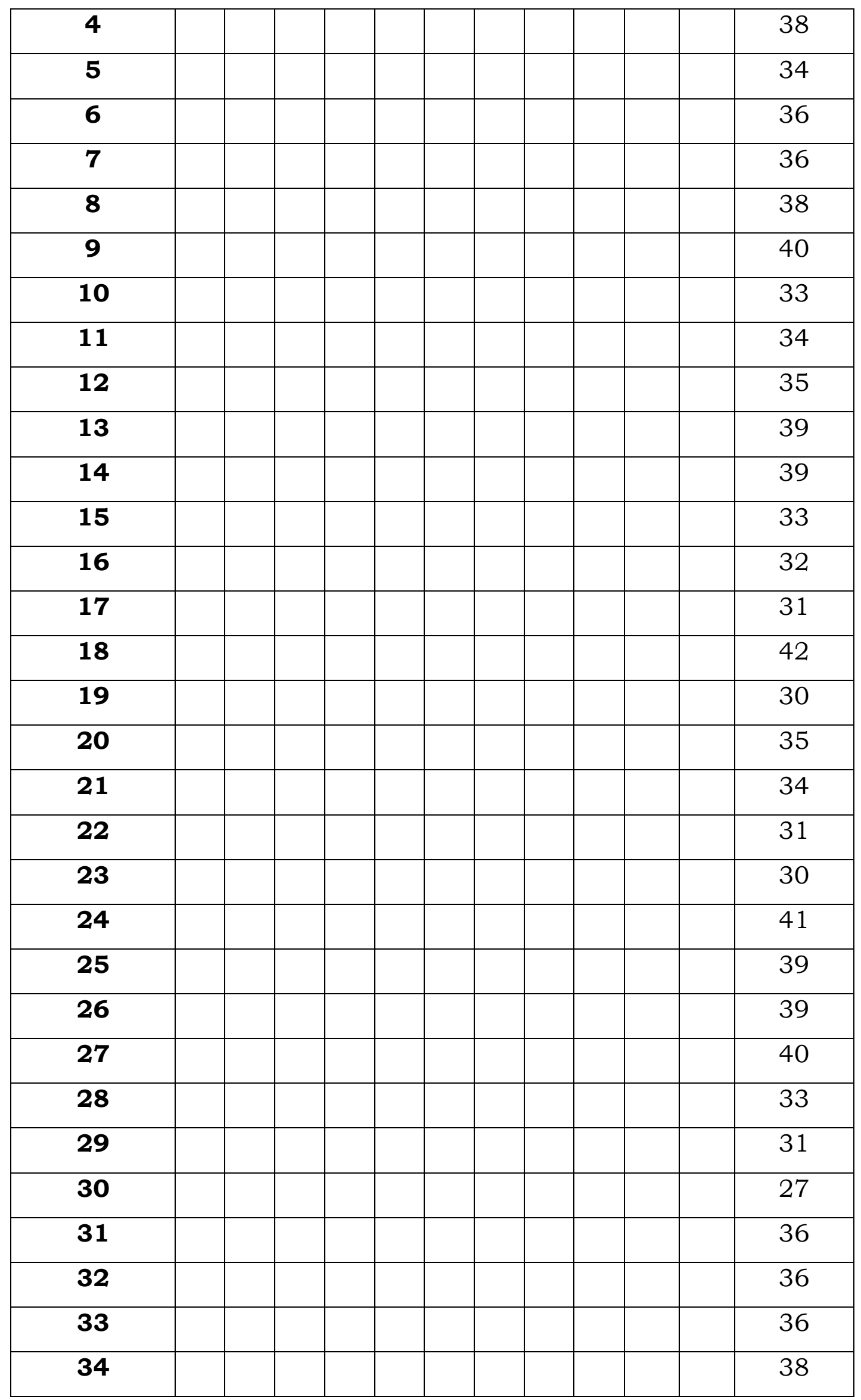




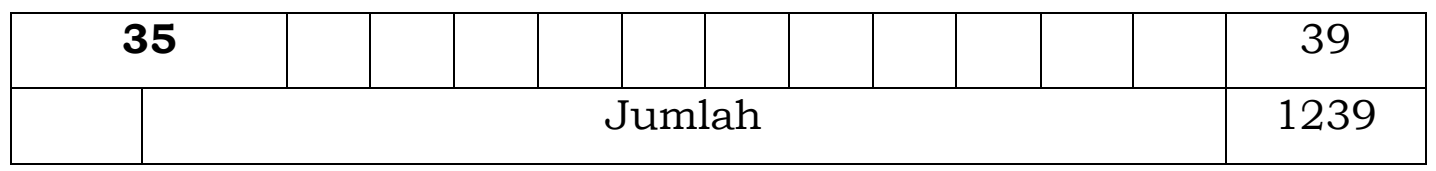

Berdasarkan Tabel 4.2 di atas diperoleh data pemberian insentif pada pustakawan di Perpustakaan Universitas Negeri Medan sebanyak 35 orang dengan 11 angket diperoleh nilai terendah 27 dan nilai tertinggi 42 .

Berikut disajikan rangkuman data hasil penelitian sebagimana Tabel 4.3 berikut.

Tabel 4.3. Rangkuman Data Hasil Penelitian

\begin{tabular}{|c|c|c|c|c|c|}
\hline Sampel & $\mathbf{Y}$ & $\mathbf{X}$ & $\mathbf{Y}^{\mathbf{2}}$ & $\mathbf{X}^{\mathbf{2}}$ & $\mathbf{X Y}$ \\
\hline $\mathbf{1}$ & 26 & 36 & 676 & 1296 & 936 \\
\hline $\mathbf{2}$ & 21 & 32 & 441 & 1024 & 672 \\
\hline $\mathbf{3}$ & 21 & 36 & 441 & 1296 & 756 \\
\hline $\mathbf{4}$ & 22 & 38 & 354 & 1444 & 836 \\
\hline $\mathbf{5}$ & 20 & 34 & 400 & 1156 & 680 \\
\hline $\mathbf{6}$ & 24 & 36 & 576 & 1296 & 864 \\
\hline $\mathbf{7}$ & 21 & 36 & 441 & 1296 & 756 \\
\hline $\mathbf{8}$ & 22 & 38 & 354 & 1444 & 836 \\
\hline $\mathbf{9}$ & 24 & 40 & 576 & 1600 & 960 \\
\hline $\mathbf{1 0}$ & 20 & 33 & 400 & 1089 & 660 \\
\hline $\mathbf{1 1}$ & 23 & 34 & 529 & 1156 & 782 \\
\hline $\mathbf{1 2}$ & 23 & 35 & 529 & 1225 & 805 \\
\hline $\mathbf{1 3}$ & 24 & 39 & 576 & 1521 & 936 \\
\hline $\mathbf{1 4}$ & 24 & 39 & 576 & 1521 & 936 \\
\hline $\mathbf{1 5}$ & 18 & 33 & 324 & 1089 & 594 \\
\hline $\mathbf{1 6}$ & 21 & 32 & 441 & 1024 & 672 \\
\hline $\mathbf{1 7}$ & 20 & 31 & 400 & 961 & 620 \\
\hline $\mathbf{1 8}$ & 27 & 42 & 729 & 1764 & 1134 \\
\hline $\mathbf{1 9}$ & 15 & 30 & 225 & 900 & 450 \\
\hline
\end{tabular}




\begin{tabular}{|c|c|c|c|c|c|}
\hline $\mathbf{2 0}$ & 23 & 35 & 529 & 1225 & 805 \\
\hline $\mathbf{2 1}$ & 21 & 34 & 441 & 1156 & 714 \\
\hline $\mathbf{2 2}$ & 18 & 31 & 324 & 961 & 558 \\
\hline $\mathbf{2 3}$ & 21 & 30 & 441 & 900 & 630 \\
\hline $\mathbf{2 4}$ & 25 & 41 & 625 & 1681 & 1025 \\
\hline $\mathbf{2 5}$ & 24 & 39 & 576 & 1521 & 936 \\
\hline $\mathbf{2 6}$ & 24 & 39 & 576 & 1521 & 936 \\
\hline $\mathbf{2 7}$ & 26 & 40 & 676 & 1600 & 1040 \\
\hline $\mathbf{2 8}$ & 17 & 33 & 289 & 1089 & 561 \\
\hline $\mathbf{2 9}$ & 19 & 31 & 361 & 961 & 589 \\
\hline $\mathbf{3 0}$ & 19 & 27 & 361 & 729 & 513 \\
\hline $\mathbf{3 1}$ & 20 & 36 & 400 & 1296 & 720 \\
\hline $\mathbf{3 2}$ & 23 & 36 & 529 & 1296 & 828 \\
\hline $\mathbf{3 3}$ & 24 & 36 & 576 & 1296 & 864 \\
\hline $\mathbf{3 4}$ & 21 & 38 & 441 & 1444 & 798 \\
\hline $\mathbf{3 5}$ & 17 & 39 & 289 & 1521 & 663 \\
\hline $\boldsymbol{\Sigma}$ & $\mathbf{7 5 8}$ & $\mathbf{1 2 3 9}$ & $\mathbf{1 6 6 8 2}$ & $\mathbf{4 4 2 9 9}$ & $\mathbf{2 7 0 6 5}$ \\
\hline
\end{tabular}

\section{Uji Kelinieran dan Keberartian Regresi $\mathbf{Y}$ atas $\mathrm{X}$}

Uji linieritas dilakukan untuk mengetahui linier atau tidaknya hubungan antara variabel bebas terhadap variabel terikat yang merupakan syarat untuk menggunakan teknik statistik dan analisis regresi, maka yang diperhatikan atau di uji adalah pengaruh variabel bebas terhadap variabel terikat, yaitu: pemberian insentif terhadap kinerja pustakawan persputakaan UNIMED.

Untuk mengetahui apakah data variabel bebas (X) linier terhadap data variabel terikat $(\mathrm{Y})$, dilakukan dengan uji regresi linear sederhana yang dikemukakan Sudjana (2002:315), dengan persamaan sebagai berikut:

$$
\hat{Y}=a+b X
$$


Dari data Tabel 4.3 di atas dihitung nilai a dan b sebagai berikut:

$\begin{array}{llll}\Sigma X & =1239 & & \Sigma \mathrm{X}^{2}=44299 \\ \Sigma \mathrm{Y} & =758 & & \Sigma \mathrm{Y}^{2}=16682 \\ \Sigma \mathrm{XY} & =27065 & \mathrm{~N} & =35\end{array}$

Selanjutnya dihitung koefisien a dan b dengan rumus:

$$
\begin{gathered}
a=\frac{(\Sigma Y) \cdot(\Sigma X)^{2}-(\Sigma X) \cdot(\Sigma X Y)}{N \cdot \Sigma X^{2}-(\Sigma X)^{2}} \\
=\frac{(758 \times 44299)-(1239 \times 27605)}{35 \times 44299-(1239)^{2}} \\
=2,940 \\
b=\frac{N \cdot(\Sigma X Y)-(\Sigma X) \cdot(\Sigma Y)}{N \cdot \Sigma X^{2}-(\Sigma X)^{2}} \\
=\frac{(35 \times 27065)-(1239 \times 758)}{35 \times 44299-(1239)^{2}} \\
=0,529
\end{gathered}
$$

Dengan demikian diperoleh persamaan regresi $\mathrm{Y}$ atas $\mathrm{X}$ adalah: $\hat{\mathrm{Y}}=$ $2,940+0,529 \mathrm{X}$. Bentuk pengaruh antara pemberian insentif terhadap kinerja pustakawan melalui persamaan $\hat{Y}=2,940+$ 
0,529 $\mathrm{X}$ dapat dilihat pada Gambar:

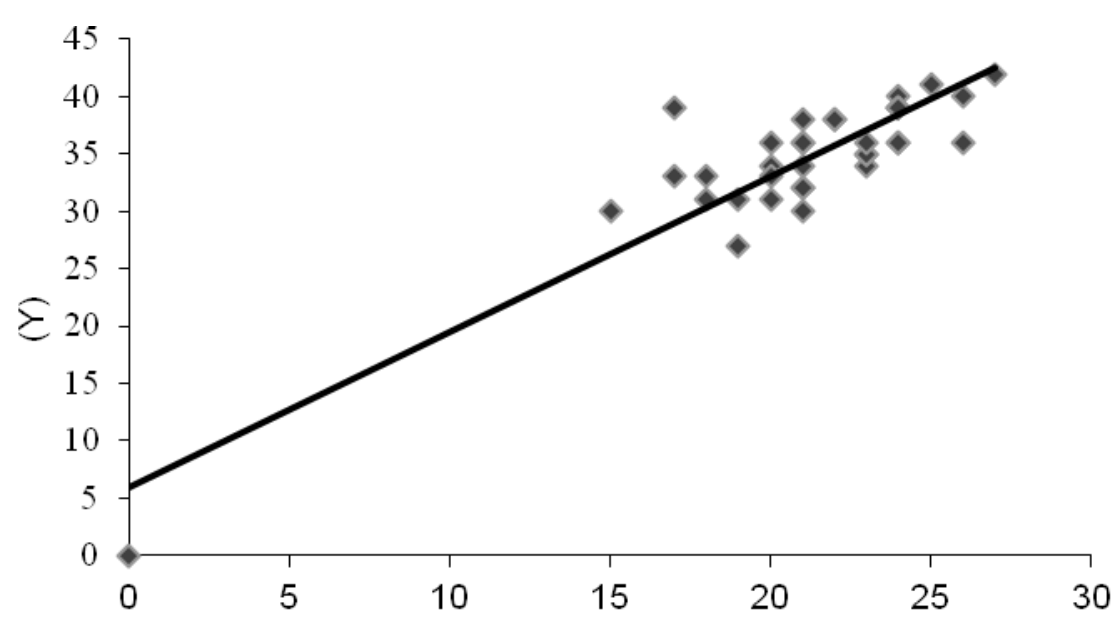

(X)

Gambar 4.5. Grafik Linier Sederhana antara X dengan Y

Dari Gambar 4.5 di atas dapat dilihat bahwa variabel X dapat mempengaruhi Y. Hal ini dapat menyatakan bahwa pengaruh pemberian insentif mempunyai pengaruh terhadap kinerja pustakawan Perpustakaan Universitas Negeri Medan. Bentuk persamaan $\mathrm{Y}$ atas $\mathrm{X}$ adalah $\hat{\mathrm{Y}}=2,940+0,529 \mathrm{X}$. Nilai $\mathrm{b}=0,529$ memiliki arti bahwa bila nilai X (insentif) naik sebesar satu unit, maka rata-rata kinerja akan mengalami peningkatan sebesar 0,529 .

\section{Pengaruh Insentif terhadap Kinerja Pustakawan Perpustakaan Universitas Negeri Medan}

Setelah diketahui skor dari masing-masing variabel, maka selanjutnya mencari apakah ada pengaruh variabel $\mathrm{X}$ terhadap variabel Y. Berdasarkan Tabel 4.3 di atas diperoleh hasil perhitungan sebagai berikut:

$\Sigma \mathrm{X}=1239 \quad \Sigma \mathrm{X}^{2}=44299$ 


$\begin{array}{llll}\Sigma \mathrm{Y} & =758 & \Sigma \mathrm{Y}^{2} & =16682 \\ \Sigma \mathrm{XY} & =27065 & \mathrm{~N} & =35\end{array}$

Kemudian dimasukkan ke rumus korelasi product moment sebagai berikut:

$$
\begin{aligned}
\mathrm{r}_{\mathrm{XY}} & =\frac{\mathrm{N} \sum \mathrm{XY}-\left(\sum \mathrm{X}\right)\left(\sum \mathrm{Y}\right)}{\sqrt{\left\{\mathrm{N} \sum \mathrm{X}^{2}\left(\sum \mathrm{X}\right)^{2}\right\}-\left\{\mathrm{N} \sum \mathrm{Y}^{2}-\left(\sum \mathrm{Y}\right)^{2}\right\}}} \\
& =\frac{(35 \times 27065)-(1239 \times 758)}{\sqrt{\left\{(35 \times 44299)-1239^{2}\right\}-\left\{(35 \times 16682)-758^{2}\right\}}} \\
& =\frac{8113}{\sqrt{142791264,00}} \\
& =\frac{8113}{11949,530} \\
& =0,679
\end{aligned}
$$

Dari hasil perhitungan di atas dapat diketahui bahwa terdapat pengaruh positif sebesar 0,679 antara pemberian insentif terhadap kinerja pustakawan UNIMED. Selanjutnya untuk dapat memberi interprestasi terhadap kuat atau rendahnya pengaruh itu, maka dapat digunakan pedoman interprestasi koefisien korelasi seperti yang ada pada Tabel 4.4 berikut.

Tabel 4.4. Interpretasi Koefesien Korelasi

\begin{tabular}{|c|c|}
\hline Interval Koefisien & Tingkat Hubungan \\
\hline $0,00-0,19$ & Sangat rendah \\
$0,20-0,39$ & Rendah \\
$0,40-0,59$ & Sedang \\
$0,60-0,79$ & Kuat \\
$0,80-1,00$ & Sangat kuat \\
\hline
\end{tabular}

Berdasarkan Tabel 4.4 di atas, maka koefisien korelasi yang ditemukan sebesar 0,679 dan termasuk pada kategori Kuat. Jadi 
terdapat pengaruh pemberian insentif terhadap kinerja yang kuat pada Pustakawan Perpustakaan Universitas Negeri Medan.

Harga $r_{X Y}$ tersebut selanjutnya dibandingkan dengan harga $r_{\text {tabel }}$. Untuk taraf signifikan 5\% dan $\mathrm{n}=35$, maka $\mathrm{r}_{\text {tabel }}=0,334$ dan $\mathrm{r}_{\mathrm{XY}}=$ 0,679. Hal ini dapat disimpulkan bahwa $r_{X Y}>r_{\text {tabel }}(0,679>0,334)$ berarti ada pengaruh signifikan/ berarti antara variabel $\mathrm{X}$ terhadap variabel $\mathrm{Y}$.

\section{Pengujian Hipotesis}

Hipotesis pada variabel ini adalah pengaruh pemberian insentif terhadap kinerja pustakawan UNIMED. Pengujian hipotesisnya adalah sebagai berikut:

Ha:Ada pengaruh pemberian insentif terhadap kinerja pustakawan Perpustakaan Universitas Negeri Medan

Ho:Tidak ada pengaruh pemberian insentif terhadap kinerja pustakawan Perpustakaan Universitas Negeri Medan

Setelah dilakukan analisis data selanjutnya dilakukan pengujian hipotesis. Untuk mengetahui apakah hipotesis ditolak atau diterima, serta mengetahui apakah ada pengaruh antara variabel $\mathrm{X}$ dan variabel $\mathrm{Y}$ maka digunakan signifikansi koefisien korelasi dengan uji-t menggunakan rumus sebagai berikut: $\mathrm{t}=\frac{\mathrm{r} \sqrt{\mathrm{n}-2}}{\sqrt{1-\mathrm{r}^{2}}}$

Distribusi t yang digunakan memiliki $d k(n-2)=d k(35-2)$ $=33$, dengan $t_{\text {tabel }}=1,70$. Berdasarkan sampel ukuran 35 dengan $r$ $=0,678$ diperoleh thitung yaitu:

$t_{\text {hitung }}=\frac{0,679 \sqrt{35-2}}{\sqrt{1-0,679^{2}}}$

$=\frac{0,679 \times 5,745}{\sqrt{1-0,679^{2}}}$ 


$$
\begin{aligned}
& =\frac{0,679 \times 5,745}{0,734} \\
& =5,312
\end{aligned}
$$

Berdasarkan perhitungan di atas diperoleh harga $t_{\text {hitung }}=$ 5,312 dengan taraf signifikan nyata $\mathrm{a}=0,05$ dengan keadaan $\mathrm{k}=$ $\mathrm{n}-2=35-2=33$. Selanjutnya Ha diterima jika $t_{\text {hitung }}>\mathrm{t}_{\text {tabel }}$. Bedasarkan daftar $t_{\text {tabel }}=1,70$ dapat dilihat bahwa $t_{\text {hitung }}>t_{\text {tabel }}$ yaitu 5,312 > 1,70. Maka dapat disimpulkan Ha diterima (bahwa terdapat pengaruh pemberian insentif terhadap kinerja pustakawan UNIMED) dan Ho ditolak (bahwa tidak terdapat pengaruh pemberian insentif terhadap kinerja pustakawan UNIMED).

Besar sumbangan determinan yang diberikan variabel pemberian insentif terhadap kinerja pustakawan adalah:

$\mathrm{D}=0,679^{2} \times 100 \%$

$=0,491 \times 100 \%$

$=49,10 \%$.

Dengan demikian pemberian insentif memberikan pengaruh sebesar 49,10\% dalam kinerja Pustakawan Perpustakaan Universitas Negeri Medan.

\section{Pembahasan Hasil}

Dari hasil penelitian diperoleh bahwa terdapat pengaruh yang positif dan signifikan antara variabel pemberian Insentif terhadap peningkatan Kinerja Pustakawan Perpustakaan Universitas Negeri Medan.

Hasil penelitian menunjukan bahwa kinerja pustakawan sudah sesuai dengan tugas pokok dan fungsi pustakawan. Selalu dapat bekerja dalam tim dan meyelesaikan tugas secara teamworkuntuk mencapai tujuan institusi dan saling menjaga hubungan bai kantar sesame pustakawan. Dukungan dari 
pimpinan dalam memberikan motivasi dapat meningkatkan kinerja dan mengoptimalkan layanan. Tetapi dorongan dan motivasi ini tidak akan banyak membantu apabila tidak ada dorongan dari dalam diri pustakawan yang bersangkutan.

Pemberian Insentif adalah penghargaan/ imbalan yang di berikan untuk memotivasi pustakawan agar motivasi dan produktivitas kerjanya tinggi, sifatnya tidak tetap atau sewaktuwaktu, dengan adanya insentif ini maka kinerja pustakawan akan naik dan ini dibuktikan dengan berpengaruh sebesar $49 \%$. Insentif ini juga adalah penghargaan yang diberikan oleh pihak pemimpin oraganisasi kepada pustakawan agar mereka bias bekerja dengan kinerja tinggi dan berkomitmen akan memajukan organisasi induknya.

Pemberian insentif bukan satu-satunya motivasi yang bisa meningkatkan kinerja para pustakawan dengan peningkatan berbagai pengetahuan, keterampilan dan pengembangan diri tersebut, maka kemungkinan kinerja para pustakawan akan menjadi optimal.

Insentif yang di berikan akan membawa dampak positif bagi para pustakawan dalam menunjukan kinerja yang baik, baik itu memberikan pelayanan yang terbaik bagi para pengguna, maupun kerjasama yang baik dalam kerja tim, serta memiliki kemampuan untuk bertindak sesuai dengan nilai, norma dan etika lingkungan kerja, pustakawan juga mempunyai kemauan dalam menyelaraskan sikap dan tindakan sebagai pustakawan professional dan sebagai pegawai yang baik dan berusaha mentaati ketentuan kerja yang berlaku di perpustakaan.

\section{Keterbatasan Penelitian}

Sebagai manusia biasa penulis tidak terlepas dari kesalahan dan kekhilafan yang berakibat dari keterbatasan berbagai faktor yang ada pada penulis. Kendala-kendala yang dihadapi sejak dari 
pembuatan, rangkaian penelitian, pelaksanaan penelitian, hingga pengolahan data seperti:

1. Terbatasnya waktu dan dana yang penulis miliki untuk melakukan riset lebih lanjut pada di Perpustakaan Universitas Negeri Medan.

2. Sulit untuk mengukur secara tepat tentang pengaruh Pemberian Insentif terhadap Peningkatan Kinerja Pustakawan karena instrumen yang digunakan hanya angket yang berjumlah 19 butir.

3. Penulis juga menyadari bahwa kekurangan pengetahuan penulis dalam membuat angket yang baik, ditambah dengan kurangnya buku-buku pedoman tentang penyusunan teori-teori yang sesuai pada pokok bahasan ini yang merupakan keterbatasan penelitian.

\section{Kesimpulan Dan Saran}

\section{Kesimpulan}

Berdasarkan hasil penelitian yang telah dilaksanakan oleh peneliti mengenai pengaruh pemberian insentif terhadap peningkatan kinerja pustakawan Perpustakaan Universitas Negeri Medan. maka penulis akan mengemukakan beberapa kesimpulan sebagai berikut:

1. Terdapat pengaruh signifikan antara pemberian insentif terhadap peningkatan kinerja pustakawan Perpustakaan Universitas Negeri Medan dengan nilai $r_{\text {hitung }}$ sebesar 0,679 dan $r_{\text {tabel }}$ sebesar 0,334, artinya $r_{\text {hitung }}>r_{\text {tabel }}$ yaitu $0,679>0,33$. Serta koefisien deskriminasi (D) sebesar 49,10\%.

2. Hasil hipotesis diperoleh thitung sebesar 5,312 dan tabel sebesar 1,70. Dari hasil tersebut maka diperoleh $t_{\text {hitung }}>t_{\text {tabel }}$ yaitu $5,312>1,70$, sehingga diperoleh kesimpulan dalam penelitian ini adalah ada pengaruh yang berarti antara pemberian insentif terhadap peningkatan kinerja pustakawan Perpustakaan Universitas Negeri Medan (Ha diterima dan Ho ditolak). 


\section{Saran}

Sejalan dengan kesimpulan yang telah dibuat, maka berikut ini dapat diberikan beberapa saran:

1. Kepada Pegawai

Disarankan kepada semua pegawai untuk mengikuti kegiatan peningkatan pengetahuan layanan informasi, sehingga pegawai dapat mengambil nilai-nilai positif dalam pemberian insentif ke arah yang lebih baik, serta mampu menerapkan dalam kehidupan sehari-hari dalam mengatasi permasalahan yang dihadapi pegawai terutama masalah belajar.

2. Kepada Pihak Perpustakaan Universitas Negeri Medan

Disarankan kepada pihak Perpustakaan Universitas Negeri Medan untuk lebih bekerjasama dan lebih terbuka kepada para pegawai, sehingga para pegawai nyaman bekerja dan mempunyai rasa kepercayaan yang besar kepada pimpinan perpustakaan. Permasalahan kesejahteraan pegawai sedikit banyak dapat terpecahkan bukan hanya karena meningkatnya kesejahteraan tetapi juga karena kenyamanan dalam bekerja sehingga ini semua akan bermuara kepada peninkatan kinerja para pustakawan. Karena dukungan yang baik dari pihak Perpustakaan Universitas Negeri Medan dapat mempermudah pegawai menyelesaikan setiap permasalahan dalam lingkaran kesehariannya.

3. Bagi Peneliti Selanjutnya

Peneliti yang tertarik untuk melakukan penelitian mengenai pemberian insentif dan peningkatan kinerja pustakawan diharapkan lebih memperhatikan perkembangan emosi pegawai di Perpustakaan Universitas Negeri Medan, dan faktor-faktor yang mempengaruhinya khususnya dari dalam diri pegawai. 


\section{Daftar Pustaka}

Dessler, Gary. (1997). Management Sumber Daya Manusia. Terjemahan. Benyamin Molan. Edisi Bahasa Indonesia. PT Prenhallind. Jakarta.

Fatimah, Ummi. (2001). Perpustakaan Sebagai Sarana Pendidikan dan Penelitian. Buletin FKP2TN, Th V, No. 1-2 JanuariDesember 2001: p. 25-34. Jember: UPT Perpustakaan Universitas Jember.

Hasibuan, Malayu S.P. (2007). Manajemen Sumber Daya Manusia Perusahaan. Bandung: PT. Bumi Aksara

Hariandja, MArihot Tua Efendi. (2002). Manajemen Sumber Daya Manusia: Pengadaan, Pengembangan, Pengkompensasian, dan Peningkatan Produktivitas Pegawai. Jakarta: Grasindo

Hadari Nawawi \& Mimi Martini. (1994). Penelitian Terapan, Yogyakarta: Gajah mada University.

Kadarisman. (2012). Manajemen Pengembangan Sumber Daya Manusia. Rajawali Pers, Jakarta

Mangkunegara A.A. Anwar Prabu. (2009). Manajemen sumber daya manusia. Remaja Rosdakarya. Bandung.

Prawirosentono.S. (1999). Manajemen Sumber Daya Manausia, Kebijakan Kinerja Karyawan. BPFE, Yogyakarta.

Ranupandojo, H., dan Suad Husnan. (1984). Manajemen Personalia, Edisi III, Yogyakarta: BPFE.

Sugiyono. (2000). Metode Penelitian Bisnis. Bandung : CV Alfabeta. 